\title{
ARTICLE
}

\section{Art, Science and the Poetry of Justice - Pragmatist Aesthetics and Its Importance for Law and Legal Education}

\author{
Special Issue on Pragmatism and Legal Education Sanne \\ Taekema \& Thomas Riesthuis (eds.)
}

Wouter de Been*

\begin{abstract}
Classic pragmatists like John Dewey entertained an encompassing notion of science. This pragmatic belief in the continuities between a scientific, ethical and cultural understanding of the world went into decline in the middle of the $20^{\text {th }}$ century. To many mid-century American and English philosophers it suggested a simplistic faith that philosophy and science could address substantive questions about values, ethics and aesthetics in a rigorous way. This critique of classic pragmatism has lost some of its force in the last few decades with the rise of neo-pragmatism, but it still has a hold over disciplines like economics and law. In this article I argue that this criticism of pragmatism is rooted in a narrow conception of what science entails and what philosophy should encompass. I primarily focus on one facet: John Dewey's work on art and aesthetics. I explain why grappling with the world aesthetically, according to Dewey, is closely related to dealing with it scientifically, for instance, through the poetic and aesthetic development of metaphors and concepts to come to terms with reality. This makes his theory of art relevant, I argue, not only to studying and understanding law, but also to teaching law
\end{abstract}

Keywords: legal research, legal education, epistemology, law, science and art.

* Wouter de Been is a legal theorist who has written widely on pragmatism and legal realism. I would like to thank the reviewers for their comments. Their critical commentary made this a much better article. Any remaining shortcomings are of course my own. I dedicate this article to the memory of Willem Witteveen, who always saw the art in law. 
John Dewey's philosophy of education rests on the axiom that the indispensable elements of the democratic way of life - scientific method as intelligence in operation, art, education - are all bound together in a single organic whole. To put the matter in other terms, all genuine experience is intelligent experience, experience guided by insight derived from science, illuminated by art, and made a common possession through education.

Albert C. Barnes (1947, p. 9).

The ordinances of religion and the power of law are efficacious as they are clothed with a pomp, a dignity and majesty that are the work of imagination. If social customs are more than uniform external modes of action, it is because they are saturated with story and transmitted meaning.

John Dewey (2005 (1934), p. 340).

Since the 1990s Hilary Putnam has articulated a forceful, pragmatically inspired rejection of the fact/value distinction and its unfortunate dominance over such fields as economics and law (Putnam 1995; Putnam 2002; Putnam \& Putnam 2017, pp. 60-63). His target was the widespread notion that economists just focus on the most efficient way to achieve a given goal, not on what goal to pursue, and legal scholars just concern themselves with what the valid rules are, not with what rules they would find desirable. Elsewhere I have argued that the hold of this maxim over today's economic and legal research is unfortunate (De Been \& Taekema 2012; De Been 2015). In this article I would like to take that argument a step further. Putnam's take on pragmatism remains fairly circumscribed. He argues that a separation between Is and Ought cannot be maintained, because scientific inquiry depends ultimately on values that are beyond the realm of facts. Theories are chosen over others because, for example, they are more elegant or parsimonious. Moreover, concepts being researched in fields such as law and economics are often substantively thick and irreducible to pure empirical facts or behaviour, such as crime, good, cruelty or equality. They are 'entangled', in the language of Putnam, with their substantive and descriptive aspects bound up together (Putnam 2002).

Although I am largely sympathetic to Putnam's analysis, the unfortunate conception his argument could give rise to is that, pragmatism can still be reduced to a species of policy science. Putnam fails to put to rest one of the stock objections to pragmatism, namely, that for all its theoretical innovation, pragmatism still basically presents an instrumental conception of public policy. What is underemphasized in Putnam's understanding of John Dewey's pragmatism is that it embraces an element of qualitative thought and protean creativity that cannot be reduced to a scientific managerial belief in 'political technology' and 'social engineering' (even though Dewey himself was responsible for these unfortunate turns of phrase and the resulting confusion). What Dewey also stressed, mainly in his later work, is the importance of the qualitative and the aesthetic. This was not an exotic new theme unrelated to his concern for science and intelligent public policy, but a crucial element of the pragmatic understanding of how people acted in, and gained warranted knowledge about, the world around them. In this article I will discuss the importance of the aesthetic in Dewey's thought, its re-emergence in the revival of 
pragmatism in the last few decades and, finally, its relevance for law and legal education.

The article, consequently, consists of three main parts. In the first section I will elaborate on Dewey's theory of art and explain why it is relevant to his wider philosophy. Dewey saw art and science as kindred endeavours, as practices rooted in similar interactional processes of the human organism with its environment. Hence, Dewey's theory of art is not only interesting for what it says about art, but also for the light it sheds on his conception of knowledge and science. Dewey's work on art and aesthetics, moreover, was shaped considerably by his 30-year friendship and collaboration with Albert C. Barnes, the chemist, industrialist, art collector and eccentric to whom Art as Experience was dedicated. The association with Barnes foregrounds the anti-elitist aspect of Dewey's notion of aesthetics, its continuity with crafts and artisanship and the culture of indigenous peoples and its importance beyond the rarefied art works in the museums and art collections. Influenced by Dewey's work on education, Barnes had conceived of his considerable collection of Impressionist, Post-Impressionist and Modernist paintings primarily as a vehicle for educational purposes and not as a museum collection. Not only the understanding of science, in other words, but also education was central to Dewey's preoccupation with art and aesthetics.

In the second section I will show that Dewey's aesthetics is not dated, but is still relevant in the work of more contemporary pragmatist philosophers and social theorists like Richard Rorty, Morton White, Mark Johnson, Richard Schusterman and Hans Joas. In different ways they have all built on Dewey's suggestion that pragmatism is more than just a programme of finding solutions to problems scientifically. For Dewey art and science were analogous practices that demanded genuine creativity and a feel for the solution that was inventive and offered a good fit within the body of knowledge and the cultural tradition. Science was not simply a matter of finding functional solutions; it was a matter of imagining creative answers. These different contemporary reconstructions of Dewey's aesthetics do not necessarily fit together seamlessly, as we shall see, but they do present a set of kindred considerations that can inform an approach to the study of, and instruction in, law.

In the third section, I will try to tease out what a reconsideration of Dewey's pragmatism in the light of his aesthetics means for law and legal education. This final section is predominantly inspired by Karl Llewellyn's ideas about what law as an academic discipline entailed and how it should be taught. Llewellyn was a great admirer of Dewey. 'Since Thomas Jefferson or Benjamin Franklin', he claimed, 'there has been nobody with the sweet childlike open eye to see things fresh, that Dewey had'. This ability 'to see it fresh', he believed, was crucially important for law and was a capacity he wanted to teach law students. Indeed, Llewellyn once asserted that his ambition was to do for jurisprudence what Dewey had done for topics like philosophy and education: 'His method of dealing with problems is still and will always be the great and needed method: Take a fresh look, look to see what is there, and what it is about, and re-pose your issues in those terms' (Quoted in Twining 1973, p. 423, n. 130). With respect to art and aesthetics, Llewellyn jurisprudence chimes with Dewey's philosophy quite well. Llewellyn's jurisprudence 
exhibits the same interest in the aesthetics of craft, the same naturalistic understanding of art and the same appreciation of the way the world can be imagined anew. When Dewey turns to the question how art can reflect the world afresh, not in painting, but in poetry, he often hearkens back to the Romantic project of conceptual reimagination, of describing experience in a new way, of formulating a fresh metaphor that organizes experience from a different vantage point. Here, Dewey seems to have been inspired, in part, by Ralph Waldo Emerson and the English Romantic poets of the 19th century, such as Wordsworth, Coleridge, Keats and Shelley, from whom Emerson took his cue. Such a reimagination and revitalization of the conceptual toolkit was what Llewellyn - coincidentally often described as 'a poet' or an 'artist' in the field of law - believed was most important in Dewey's approach to law. ${ }^{1}$ Llewellyn, as we shall see, also drew on an English Romantic, Thomas Carlyle, and argued renewal of the terminology was important to keep legal rules and concepts from becoming dry and lifeless. The final section will focus on the question of how this 'great and needed method' of dealing with problems, the method of 'seeing things fresh', can inform legal education.

\section{Art as Experience}

Dewey's perspective on art is not commonly put centre stage in the philosophical debate on the pragmatic theory of science. In their recent comprehensive discussion of pragmatism, Pragmatism as a Way of Life: The Lasting Legacy of William James and John Dewey (2017), Hilary and Ruth Anna Putnam only treat art briefly in passing and there is no mention of aesthetics in the index. The aspect of Dewey's pragmatism that usually gets drawn out in discussions of science and epistemology is his rejection of the fact/value dichotomy and his instrumentalism. ${ }^{2}$ Authors sympathetic to pragmatism typically note that facts are theory laden and that this dependence on theory draws scientific inquiry inevitably into the realm of people's projects and ends. The value side of the dichotomy is then discussed primarily in terms of morality. 'Is' and 'ought' cannot be neatly separated if you take a pragmatic perspective. A melioristic concern with human flourishing is integral to scientific inquiry. For a pragmatist, to put it differently, scientific inquiry is unavoidably a human practice, rooted in human experience and reflecting human ends, needs and interests. What the renewed interest in Dewey's aesthetics among a number of contemporary philosophers draws attention to, however, is its importance for the question how situated human beings deal with the world around them. Dewey suggests that when people confront the problems thrown up by their surroundings they are not only engaged rationally and ethically, but also artistically and creatively. ${ }^{3}$

1 See: William Twining (1973, pp. 121-123) and Steven Alan Childress in the Foreword to Karl Llewellyn (2016 (1960)), p. i.

2 See for instance: Putnam and Putnam (2017), Putnam (2002), Putnam (1995), White (2002).

3 Some authors suggest that he turned to the topics of art and religion late in his life in Art as Experience (1934) and A Common Faith (1934) because he was worried that critics increasingly reduced his work in philosophy to a coarse instrumentalism or reductive functionalism. See e.g.: Romain Mollard (2013, pp. 3-4); Hans Joas (1996, pp. 141-143). 


\subsection{Dewey on Art}

In Art as Experience Dewey defends the notion that art is part and parcel of the way people interact with their environment. To a degree his view of art was an extension of the themes that were central to his pragmatist outlook, that is, his naturalism, his faith in democracy and his focus on social interaction. There is an effort to naturalize art in Art as Experience that echoes his attempt to naturalize science and ethics in his wider philosophy. Indeed, there are precursors to Dewey's ideas on art and aesthetics, for instance, in Experience and Nature and his essay 'Qualitative Thought' that root aesthetics in the emotional response of human beings, or even organisms, to processes and objects in their living environment (Dewey 1988 (1930); Dewey 1997 (1925)). You could even argue that the notion of 'experience' in Dewey's thought as something that emerges from the dynamic interaction of our bodies, our minds and our environment can be traced back, through Emerson, to the English Romantic poets, who presented an alternative to the materialism and empiricism of the Enlightenment by emphasizing the role of the imagination in experience. If Dewey finds art and aesthetics in the way human beings understand and act in the world, then maybe it is because his notion of 'experience' developed, in part, out of the Romantic reaction to the empiricism and materialism of the Enlightenment in the first place. ${ }^{4}$ In Art as Experience there is also an endeavour to democratize art, to see it as continuous with common experiences of beauty, with folk art and with the creativity of craftsmanship. Moreover, Dewey democratizes art in the sense that it is something that should be part and parcel of the work and the life of ordinary people, not a niche concern of the few. In Art as Experience he claims that art has always penetrated the full spectrum of social activity and permeated all the artefacts made by a given culture: its law, its architecture, its religion, its manufacturing and the like. Modern industrial society seemed out of kilter in this respect. Finally, there is an interactionist understanding of art, in which art is presented as a social construction, in which works of art - while expressing the distinct hand of the individual artist - take shape within a community of fellow artists, with a public, with critics and against the background of a cultural tradition.

These familiar pragmatic hallmarks, however, were further shaped by his association with Albert Barnes. By his own admission Dewey lacked a thorough background in the visual arts and learnt a great deal about painting through his friendship and collaboration with Barnes and through their joint trips to galleries and museums in the United States and Europe. ${ }^{5}$ Barnes, by all accounts, was a difficult man. He grew up poor, but became extremely wealthy with his invention of the antiseptic Argyrol. Barnes used his wealth to compile one of the great art collec-

4 In Chapter 11 of Art as Experience Dewey juxtaposes a tabula rasa conception of the mind - with which he probably referred to the empiricism of John Locke - with the perspective offered by Coleridge in his reflections on poetry and art. The Coleridge critique of Lockean empiricism was a seminal argument for American transcendentalists and Emerson (see: Menand 2001, pp. 244-247; Gura 2008, pp. 51-53) with which Dewey was quite familiar.

5 This is not only clear from his many references to Barnes in his discussions of art in Art as Experience - a book dedicated to Barnes - but also from the extensive praise he expresses for the insights of Barnes and his work at the Barnes Foundation in the preface. Finally, it becomes clear from the extensive correspondence between Dewey and Barnes (see: George Hein, 2017). 
tions of the United States, which not only included a large number of Impressionist and Post-Impressionist masters, but also a large collection of African and Native American folk art and objects of Colonial American craftsmanship. This collection, and the art Dewey saw on trips together with Barnes to museums in Europe and the United States, supplied many of the examples discussed in his book.

Apart from Barnes' taste in painting, his vision of creating an educational institution around his art collection both affirmed and further influenced Dewey's philosophical analysis of art. Barnes himself had been inspired by Dewey's ideas on education when he first conceived of his educational art programme - which was one of the sources of their friendship and collaboration - but when he first put together the art programme he also drew on the ideas of the American Arts and Crafts movement, which are also present in Dewey's thinking about art. ${ }^{6}$ The Arts and Craft movement was originally a British phenomenon. It was a movement concerned with the way the industrial revolution and machine production had severed the link between the artist and his work. Mechanization had separated the craftsman from the artefacts he produced. The Arts and Crafts movement advocated traditional techniques and natural products. It wanted to reconnect people with their materials and their creations through artisanal work. The social and cultural analysis of the Arts and Crafts movement not only reflected a Romantic aversion to 'the dark satanic mills' of industrialization (William Blake 1804), but also was close to the Marxist notion of 'alienation' - the idea that in the industrial age work was no longer an act of self-realization or self-actualization. Industrial workers were cogs in the machine, facilitating the mass production of commodities that someone else had designed. Udo Kultermann notes correctly that 'Dewey's art theory has heterogeneous elements that relate it to social reform movement, rather than philosophical reasoning about art' (Kultermann 1990, p. 21).

Barnes' affinity with the Arts and Crafts movement found expression in his art centre. For example, he presented his art in so-called ensembles that combined invaluable paintings by the great Impressionist masters with iron door hinges or cutlery made by anonymous Antebellum American metal workers or with African sculptures or Native American textiles. These ensembles were meant to draw out associations and similarities and were used in his teaching courses. Moreover, they highlighted the commonalities Barnes saw between folk art, artisanship and high art. Barnes also practiced the egalitarianism of the Arts and Crafts movement - he used his collection to teach his own workers, many of whom were African American and many of whom were women. He was fiercely anti-elitist. His educational art programme was open to working people, but places were limited to 1,200 a week. ${ }^{7}$

6 John Dewey was quite taken with the educational art programme Barnes had set up. In the preface to Art as Experience he wrote: 'Whatever is sound in this volume is due more than I can say to the great educational work carried on in the Barnes Foundation. That work is of a pioneer quality comparable to the best that has been done in any field during the present generation, that of science not excepted' (2005 (1934), p. Viii). For the influence of the Arts and Crafts movement see: Morris Vogel (1991, pp. 158-159), and Udo Kultermann (1990, p. 21).

7 The Barnes ensembles persist to this day and classes in the Barnes method are still offered, but facing bankruptcy the Barnes Collection moved from its Merion home to a modern museum building in Philadelphia in 2012 and opened up to the general public. 
He was notoriously suspicious of the art establishment and often rejected intellectuals' and critics' access to his collection. ${ }^{8}$

Barnes' conceptions of the purpose and the role of art in society are consonant with Dewey's discussion in Art as Experience. Dewey starts Art as Experience with a withering critique of the way capitalistic, industrialized societies have completely compartmentalized art and segregated it from life. Art has been turned into something alien to ordinary existence and stored away in museums. It has been cut loose from the aesthetic impulse that animates art in the ordinary course of life. Dewey provides a number of reasons for this transformation of art into rarefied props in museums and galleries. Most European art museums, he complains, are 'memorials of the rise of nationalism and imperialism'. Every capital must have its art museum 'devoted in part to exhibiting the greatness of its historic past, and, in other part, to exhibiting the loot gathered by its monarchs in conquest of other nations'. For the 'nouveau riches' art provides 'evidence of good standing in the realm of higher culture' (Dewey 2005 (1934), p. 7). Just like stocks and bonds, the wealthy collect 'artistic bijoux' to establish their standing in the world. The underlying cause of this compartmentalization, however, was that industrialized production left little room for artistic expression within the course of everyday existence. Modern modes of production and consumption led to an alienation from artistic experience and an acceptance that art is something completely separate from ordinary life (Dewey 2005 (1934), pp. 6-9). At the end of Art as Experience Dewey echoes a central tenet of the Arts and Crafts critique:

What is true is that art itself is not secure under modern conditions until the mass of men and women who do the useful work of the world have the opportunity to be free in conducting the processes of production and are richly endowed in capacity for enjoying the fruits of collective work. (Dewey 2005 (1934), p. 358 $)^{9}$

Dewey was interested in poetry well before he met Barnes and experimented with it in private. The possibilities of poetic expression clearly interested him and informed his analysis in Art as Experience. Yet, Barnes had a considerable influence on the other types of art that Dewey focused on. The discussion in Art as Experience draws heavily on the things that Barnes collected. ${ }^{10}$ As a result, there is a certain cast to the art that Dewey discusses in Art as Experience. Furthermore, Barnes provided Dewey with a real-life model of how art could be democratized and used in education.

8 The first shows of his art collection met with ridicule among the Philadelphia establishment, which made Barnes intolerant towards any sign of cultural superiority or pomposity. He was notorious for writing rude rejection letters, which were sometimes signed by his dog. Not only scholars and art critics received such letters, but also luminaries like T.S. Eliot and Le Corbusier. See Alistair Sooke (2015).

9 Although they are not mentioned, the passage is suggestive of the notions of William Morris and John Ruskin.

10 The poems were published posthumously in 1977 in The Poems of John Dewey edited by Jo Ann Boydston. 


\subsection{Dewey's Naturalization of Art}

One of the central notions that Dewey addresses in his treatise on aesthetics is the dichotomy between nature and culture. This dichotomy provided the basic framework for the way people understood art in the late 19th and early 20th centuries. In the 19th century, people treated indigenous peoples and their cultural artefacts as things that were part of nature and that needed to be understood as something qualitatively different from the works of art produced by 'civilized' societies. This understanding of indigenous peoples is reflected in contemporary terminology that categorized them as 'savages' and 'primitives'. It is an understanding that informs the organization and the collections of many 19th-century museums of natural history to this day. In Europe and North America, there was a natural history vogue in the 19th century that led to the foundation of a great many natural history museums. A sizable number of them contained sections with artefacts from 'primitive' cultures. The famous American Museum of Natural History in New York, for instance, does not only display dinosaur skeletons, butterfly collections, and stuffed animals, but also contains a range of dioramas depicting indigenous cultures from different continents and different time periods. ${ }^{11}$ For most of the 19th century, Don Fowler notes, 'Anthropology fell within the realm of natural history and hence ultimately into the halls of natural history museums' (Fowler 2003, p. 14). This made the cultural artefacts of indigenous peoples something that was displayed together with fossils and specimens of plants and wild life. 'Because "savage" folk were seen to be "closer to nature" than "civilized" folk', Fowler explains, "they were considered to be part of the natural world; hence, they fell within the province of natural history' (Fowler 2003, p. 15). As a result, the art of 'primitive' people, who lived close to nature, was treated as part of the natural world, whereas the art of 'civilized' people, who were considered to bring human culture and intelligence to bear on their artefacts, was part of art history and belonged in museums of fine arts.

This dichotomy between culture and nature is something Dewey tried to dissolve in his philosophy and his view on aesthetics. He sought to naturalize art, explain how it evolved out of the interaction between the living organism and its environment. Basically, in Art as Experience, he argues that all artistic expression and enjoyment is grounded in the aesthetic experiences we have in our everyday lives. His purpose, he explains, is 'that of recovering the continuity of esthetic experience with normal processes of living' (Dewey 2005 (1934), p. 9). The art of indigenous people and the art in the museum are rooted in the same basic encounter with the aesthetic in the interaction with the world - a conception that Barnes ex-

11 That is why in the blockbuster Hollywood comedy Night at the Museum, set in the American Museum of Natural History, not only the stuffed animals come alive, but also Neanderthals, Huns, native Americans and Mayans. These dioramas have become increasingly problematic. Recently, the American Museum of Natural History in New York has attached signs on one of the dioramas with Peter Stuyvesant meeting members of the Lenape tribe, warning visitors of the many cultural stereotypes of native Americans in the display. See the Museum website: www.amnh.org/ exhibitions/permanent/theodore-roosevelt-memorial/hall/old-new-york-diorama (visited 26 December 2020). 
pressed with his collection of primitive art, works of artisanship and high art in his Merion art centre.

This naturalization of art and aesthetics and elaboration on the way the senses and the mind constructed the experience of reality is the central contribution of Dewey's aesthetics. At the core of this understanding was the central pragmatic conception of 'experience'. In Art as Experience, Dewey distinguished between 'experience at large' and 'having an experience'. When you 'experience things at large', you are aware of the tumble of events around you, you register the stream of happenstance occurrences that life consists of, without a clear beginning or end. When you 'have an experience', however, you are aware of a rounded and complete occurrence that is memorable and noteworthy. These experiences, Dewey argues, we mark out as significant, as 'real experiences':

It may have been something of tremendous importance - a quarrel with one who was once an intimate, a catastrophe finally averted by a hair's breadth. Or it may have been something that in comparison was slight - and which perhaps because of its very slightness illustrates all the better what is to be an experience. There is that meal in a Paris restaurant of which one says 'that was an experience'. It stands out as an enduring memorial of what food may be. Then there is that storm one went through in crossing the Atlantic - the storm that seemed in its fury, as it was experienced, to sum up in itself all that a storm can be, complete in itself, standing out because marked out from what went before and what came after. (Dewey 2005 (1934), p. 37)

Hence, Dewey suggests that 'the esthetic is no intruder in experience from without' but 'the clarified and intensified development of traits that belong to every normally complete experience' (Dewey 2005 (1934), p. 48). The aesthetic is an aspect of 'having an experience', of noting an occurrence in the round as a meaningful event. In observing reality we are not simply registering a set of empirical objects and happenings in a detached fashion, but also marking out a part of, and forming an emotional response to, our living environment as involved inhabitants of it.

\subsection{Continuity Between Art and Science}

For Dewey self-contained and recognizable experiences like these, which seem to convey something meaningful, are not only the stuff of aesthetics, but also of science. These 'real experiences' are emblematic - they reveal something about a phenomenon to the person who undergoes the experience (and who in part also creates and authors that experience, as we shall see shortly). The difference between a scientific and an aesthetic experience is mainly a matter of emphasis. The artist attends to these demarcated experiences for their possibilities. ' $\mathrm{H}]$ e does not shun moments of resistance and tension', according to Dewey, but 'cultivates them, not for their own sake but because of their potentialities, bringing to living consciousness an experience that is unified and total'. The scientist is also interested in experiences, 'in situations wherein tension between the matter of observation and of thought is marked', but mainly to resolve them. Thus, Dewey contends, the differ- 
ence between the artist and the scientist is 'the place where the emphasis falls in the constant rhythm that marks the interaction of the live creature with his surroundings' (Dewey 2005 (1934), p. 14).

Although their methods and techniques are completely different, according to Dewey, the distinction between scientists and artists is not a difference between people who reason and people who feel. Scientists, Dewey claims, 'do not operate by conscious wit and will to anything like the extent popularly supposed'. Scientific research cannot be reduced to the logical and disinterested resolution of a problem, but involves emotional engagement with the research subject (Dewey 2005 (1934), p. 76). Both science and art are practices that involve a creative reconstruction of the world by scientists and artists, respectively. This role of emotion in cognition, we shall see in the next section, is a central tenet of a number of neo-pragmatist theorists.

Art, then, is not something that stands opposed to science, for Dewey; rather, both stand opposed to the routine and the standard on one side, and the loose and the lax on the other:

The enemies of the esthetic are neither the practical nor the intellectual. They are the humdrum; slackness of loose ends; submission to convention in practice and intellectual procedure. Rigid abstinence, coerced submission, tightness on one side and dissipation, incoherence and aimless indulgence on the other, are deviations in opposite directions from the unity of experience. (Dewey 2005 (1934), p. 42)

Both science and art involve an open engagement with a circumscribed experience in the whole. Neither dealing with it in a customary, routine fashion, nor registering it in a heedless and inattentive way will bring out the aesthetic quality or lead to intellectual insight.

Morton White rightly observes that Dewey does not only make 'the obvious point that an artist who is a producer must be an esthetic perceiver but he also says that an esthetic perceiver who is not an artist must be creative' (White 2005 (2002), p. 30). But what is the relationship between these two? Clearly, for Dewey, these two perspectives are connected and interpenetrate. The creativity of the aesthetic perceiver is not unconstrained. A work of art is open to different interpretations, but it is not an occasion for unbridled association. It communicates a certain meaning to critics and members of the public. For Dewey works of art are a sort of language - although some forms of artistic expression are impossible to articulate in words - with each art using a different medium, a different language:

[A] beholder must create his own experience. And his creation must include relations comparable to those which the original producer underwent. They are not the same in any literal sense. But with the perceiver, as with the artist, there must be an ordering of the elements of the whole that is in form, although not in details, the same as the process of organization the creator of the work consciously experienced. (Dewey 2005 (1934), p. 56) 
The perceiver and the critic are not passive onlookers; they are creative reconstructors of art. Their reconstruction is not a complete free-for-all, however. It is rooted not only in the aesthetic experience that gave rise to the work of art, but also in a certain commonality of form and substance. For Dewey, therefore, art is irreducibly a social phenomenon. 'The material out of which a work of art is composed belongs to the common world rather than to the self', he states. However, according to Dewey, there is also always an element of novelty and individuality: 'the self assimilates that material in a distinctive way to reissue it into the public world in a form that builds a new object' (Dewey 2005 (1934), p. 112). This new object, then, becomes part of the public world and part of the background against which new works of art are created.

For White such discussions in Art as Experience of art as a sort of language, or medium, conveying things that belong 'to the common world' suggest a relapse into dualism, a dualism which Dewey rejects in his wider philosophy. ${ }^{12}$ Richard Rorty is also sceptical of the argument developed in Art as Experience and interprets Dewey's talk of 'art as experience' as a relapse into essentialism and foundationalism. Dewey, however, did not see these problems and claimed that the meaning of objects of art is not 'clarified and concentrated by thought working laboriously upon them', nor by a 'a world of mere sense', but by the merging together of them 'by creation of a new experience' (Dewey 2005 (1934), p. 138).

\subsection{Poetry in Dewey's Aesthetics}

Dewey's association with Barnes left a strong mark on Art as Experience. Barnes' main interest was painting, and Dewey spends a lot of attention on the visual arts. Dewey's notion of art as something that is intertwined with the general human occurrence of 'having an experience' also seems to fit most readily with the visual arts. (Even works of abstract art, he argues, in the end are representations of general shapes abstracted from experienced objects, not pure forms unrelated to reality (Dewey 2005 (1934), p. 97).) To highlight how art is rooted in experience, Dewey, for instance, draws attention to the way the Impressionists and the Pointillists foreground how colours work, how they are affected by surrounding colours and how the eye fuses the dotted colours of the Pointillist into a 'perceived object' (Dewey 2005 (1934), pp. 126-127). These are reorderings of the perceived objects that enhance the expressiveness of the painting and make us see the world in a new light, Dewey contends (Dewey 2005 (1934), p. 98).

This transformation of experience, as we saw earlier, is also something that Dewey associates with poetry - especially the poetry of the Romantics, for whom descriptions of nature were just as much about the inner as the outer world. Words and language lack the detail of painting. The endless shades of colour and differences of form are impossible to express in words which necessarily refer to broad categories of objects and phenomena. But when words are used in the context of po-

12 Morton White rejects the solution of 'experience' as a sort of fluid synthesis of the sensory input from the outside world and the conceptions of the mind that organize that input. It leads either to a dualism between the analytic and synthetic if the interaction with experience is 'ideational' or to a mind-body dualism if the influence is between 'the outside interaction and the inside direct experience' (2002, p. 40). 
etry, Dewey argues, 'they serve their poetic purpose in the degree in which they summon and evoke into active operation the vital responses that are present whenever we experience qualities'. In a passage that seems to presage present-day cognitive linguistics and the notion of embodiment, Dewey subscribes to the famous line of the English poet A.E. Housman - yet another Romantic in Dewey's discussion - that poetry to him seemed 'more physical than intellectual'. 'I should question the literal truth of the saying that poetry is more physical than intellectual', Dewey comments:

But that it is more than intellectual, because it absorbs the intellectual into immediate qualities that are experienced through senses that belong to the vital body, seems to me so indubitable as to justify the exaggeration contained in the saying as against the idea that qualities are universals intuited through the intellect. (Dewey 2005 (1934), pp. 224-225)

The vivid and visceral responses that poetic language evokes in readers are not merely a recurrence of familiar experiences. They are responses that can break open received understanding. Dewey in the last pages of Art as Experience discusses the morality of art. He explains that art is not valuable because it teaches us moral lessons, but because it shows us how the world can be looked at differently. Good poetry makes new connections, creates new meaning, shows how experience can be reorganized and new possibilities can be imagined. Poetry does not provide moral lessons, but provides the new understandings and perspectives that can help people imagine new possibilities and contrast them with the way the world is. This argument is close to Percy Bysshe Shelley's classic conception of poetry in 'A Defence of Poetry', which is discussed at length in the concluding paragraphs of Art as Experience. In the sense of poetry reimagining the world in Shelleyan spirit, Dewey claims 'art is more moral than moralities'. Moralities, Dewey states, often become 'consecrations of the status quo, reflections of custom, reënforcements of the established order'. Poetry, and art generally, on the other hand, have been 'the means of keeping alive the sense of purposes that outrun evidence and of meanings that transcend indurated habit'. This is why, Dewey argues in Shelleyan fashion, that the 'moral prophets of humanity have always been poets even though they spoke in free verse or by parable' (Dewey 2005 (1934), p. 362).

What Dewey suggests in Art as Experience is that the conceptual work of recasting terminology and what today is sometimes called 'reframing' is closely related to the domain of poetry and aesthetics. (Poetry, it is good to remember, derives from the Greek verb poiein, to shape into form, or to make.) The scientist and the artist both cast a fresh eye on the living environment to see things in a different light, to develop new metaphors, to create new meaning. They might do this in order to make things work better, to further understanding or simply to bring out a new, entrancing perspective. This is how Dewey thought the work of the scientist and the artist were similar, and explains why he believed the aesthetic was also relevant for an understanding of scientific knowledge. In poetry this conception of the poet as a pioneer of new understanding is not new; it has been around at least since the Romantic era. In recent decades Dewey's aesthetics has experienced a revival in 
pragmatic theory. Dewey's theory has been picked up in the somaesthetics of Richard Shusterman, the action theory of Hans Joas, the cognitive linguistics of Mark Johnson and in the legal theory of Stephen Winter. These theories focus on a range of topics within Dewey's aesthetics. What all these diverse theories have in common, however, is the space they seek to create for creativity and renewal.

\section{The Revival of Pragmatic Aesthetics}

Dewey's aesthetics was not well positioned to become an influential treatise in the middle of the 20th century. Pragmatism went out of fashion, and the analytic philosophers who became dominant in Anglo-American academics on the whole thought it was a work of loose speculation, not of systematic argument (Shusterman 2014, p. 19). The focus of professional philosophy, at least in the Anglophone world, was on science and epistemology and not on art or culture (White 2005, pp. 9-20; Rorty 1999, p. 31). In Continental Europe a similar, single-minded focus on science and epistemology did not occur in academic philosophy, but there Dewey's pragmatism was widely rejected as a plea for instrumentalist policy science (Joas 1993, pp. 2, 113). On both sides of the Atlantic, in addition, philosophy increasingly focused on language and went through their separate 'linguistic turns'. Whether the source was Wittgenstein and ideal/ordinary language philosophy in the United States and Britain, or De Saussure and (post)-structuralism in Europe, philosophy came to be preoccupied with the relationship between language and reality. Dewey's central notion of experience, with its extralinguistic dimension and its attention for the role of the body and the senses in the way the world was experienced, did not suit this centralization of language in philosophy. ${ }^{13}$

A number of developments, often referred to generically as the 'naturalization of philosophy', have changed the fortunes of Dewey's aesthetics in the last few decades and opened the door for a return of Dewey's work on aesthetics. In this middle section I will sketch some of the authors important in this revival of pragmatist aesthetics. First, I will discuss Richard Rorty, the philosopher most responsible for the revival of pragmatism, and Richard Shusterman, who, in turn, developed Rorty's thought into a pragmatist aesthetics that moves beyond the linguistic turn and embraces 'experience' in his 'somaesthetics'. Second, I will discuss Hilary Putnam and Morton White, who remain closer to John Dewey's commitment to science, but widen the range of fields and disciplines this applies to, to include questions of value and aesthetics. Third, I will discuss Hans Joas, who applies Dewey's concerns about aesthetics and craft in social theory. And, finally, I will discuss the second-generation cognitive science of philosopher Mark Johnson and legal theorist Stephen Winter, for whom Art as Experience is an important and currently relevant treatise in their reflections on law. 


\subsection{Richard Rorty, Richard Shusterman and the Revival of Pragmatist Aesthetics}

Although Richard Rorty is the philosopher most responsible for the revival of pragmatism in the latter part of the 20th century, and although aesthetics, art and especially literature are central to his thought, Art as Experience is strangely absent from his discussions. Richard Shusterman rightly points out that the reason for this was that he hated the key concept of 'experience' in Dewey's classic on aesthetics (Shusterman 2010, pp. 70-71). Before Rorty was associated with the revival of pragmatism, he was principally associated with the 'linguistic turn', and his approach remained linguicentric even after he moved away from the analytic tradition he was trained in. ${ }^{14}$ For Rorty, what differentiated neo-pragmatists like him from classical pragmatists like Dewey was exactly the latter's incessant talk about 'experience' and the focus of his generation of philosophers on language (Rorty 1999, pp. 24-25). This did not mean that Rorty neglected art and aesthetics in his later pragmatist work, but for him it was tied up with textual expression, with discourse, narrative and poetry rather than sensory experience. He feared that talk of experience would lead you into a dualist trap, with an artist finding or observing some experientially immediate phenomenon or process, not pre-shaped by linguistic categorization, to reflect in a work of art. Rorty's alternative to Dewey was largely to choose or move towards a more interesting and imaginative discourse, whenever possible, to replace a drab and unimaginative one. This seems to suggest a latitude of discursive freedom untethered from sensory experience that is more characteristic of European post-structuralism than Dewey's pragmatism.

Richard Shusterman has been greatly influenced by Rorty's linguistic pragmatism, but also by Dewey's aesthetics, and in his work he has tried to wed these two elements in his notion of somaesthetics. Rorty, Shusterman states, not only revived pragmatism, but by foregrounding its aesthetic and literary dimension, he 'made pragmatism a serious player in humanistic culture at large, transforming its older image as a dull, overly rationalistic instrumentalism that cared little for the arts and the yearnings of imagination' (Shusterman 2010, p. 69). Yet, at the same time, Shusterman is critical of Rorty's strict textualism and finds Dewey's experiential aesthetics more persuasive. Experience is just as much about reflecting, as about making and forming, some particular phenomenon out there. Moreover, it is something that involves all the senses and cannot be reduced to discourse only (Shusterman 2010, pp. 74-75). Somaesthetics focuses on the way our senses and body shape the way we experience reality, not just in high art, but in the whole spectrum of human activity. This brings it close to second-generation cognitive science, which will be discussed shortly, but Shusterman conceives of it principally as an independent philosophical approach (Shusterman 2013, pp. 49-50).

\subsection{Hilary Putnam and Morton White: Neo-Pragmatist Alternatives}

Putnam and White present versions of pragmatism that start out with a core commitment to scientific method, but try to extend that method to cover fields such as morality, history, law, economics, religion and aesthetics. I discussed Putnam, ear- 
lier. Putnam deplores the strict distinction between facts and values that presently informs disciplines like economics and law and their respective claims to objectivity, and through a careful reconstruction of the fact/value dichotomy he opens them up to the inclusion of values. Putnam, however, frames these values ethically, rather than aesthetically. When he discusses the pragmatic theory of knowledge, he draws on Quine's famous claim that scientific facts and scientific theories cannot be separated, but interpenetrate. Quine's famous metaphor for scientific knowledge - 'the lore of our fathers' - was that of a pale grey fabric 'black with fact and white with convention'. His point was that the fabric consisted of both empirical facts and theoretical conventions to frame those facts, which could not be disentangled. Indeed, there were no reasons to suppose, Quine claimed, 'that there are any quite black threads in it, or any white ones' (Quine 1960, p. 374). In other words, fact and convention, interpenetrate. Facts were not theoretically innocent, but, to a certain extent, creatures of a given theory. Quine's metaphor also includes a clear reference to the body of knowledge as an integrated whole with a history 'the lore of our fathers' - which underscored its conventional nature.

Hilary Putnam has taken this Quinean argument a step further: he has argued forcefully that once you give up the duality between fact and theory, once you accept that facts are shaped by the contingent conceptual tools we use to deal with our environment, then it also becomes hard to maintain a strict separation between fact and value. According to Putnam, when you recognize that the facts are coloured by theoretical conventions underlying the research, those facts and theoretical conventions can no longer be easily demarcated from the wider values and moral considerations that inform that research. Hence, 'the pale grey fabric' of scientific knowledge, with its black threads of facts and white threads of convention, is also shot through with threads that are red with value (Putnam 1995, p. 18). There is ineluctably a value element in scientific knowledge for Putnam, although this does not quite seem to take the expansive notion of the aesthetic that Dewey allows for in his account of scientific inquiry.

In A Philosophy of Culture, Morton White does consider Dewey's aesthetics, as part of his wider project of formulating a 'holistic pragmatism', a philosophical approach that embraces all aspects of human culture, from law to religion and from art to history. White starts his explanation of holistic pragmatism with a quote from Quine, too, the last line of his classic article 'Two Dogmas of Empiricism': 'Each man is given a heritage plus a continuing barrage of sensory stimulation; and the considerations which guide him in warping his scientific heritage to fit his continuing sensory promptings are, where rational, pragmatic' (Quine 1953, p. 43). For White this sums up the notion of holistic pragmatism in a nutshell. There are no truths that are not empirical. The 'heritage' of scientific knowledge and the procedures of scientific methodology are conventions that are revisable, if necessary, 'to fit' the 'continuing barrage of sensory stimulation'. Thus, White argues, the holistic pragmatist may start out by empirically describing the actual routines and conventional behaviour of scientists in a certain field. Then, when these routines prove to be successful, she may turn them into a rule or a law or an ethical norm. Hence, for White there is not a single 'scientific' method, but a loose set of kindred scientific disciplines, each with their own rules and conventions and with proven 
practices and insights that will only be dislodged if there are overwhelmingly compelling reasons (White 2005 (2002), pp. 179-181). ${ }^{15}$

White presents a view of 'holistic pragmatism' that is methodologically gregarious and embraces a wide range of disciplines, but it does seem to favour disciplinary compartmentalization. If the disciplinary routines of a field like aesthetics should be taken as a point of departure, then does that allow for aesthetic considerations crossing over to science or law or cognitive linguistics? The implication of White's approach seems to vitiate against those possibilities, but when he explains why Dewey's aesthetics is still important and deserves our attention, he stresses themes that do spill over into science and cognition:

Dewey's contribution to the philosophy of art lies primarily in his recognition of the continuity between art and more primitive forms of interaction between the organism and its environment, in his recognition of the similarities between art and science, in his view of the stages of artistic creation, and in his view that the philosopher engages in empirical inquiry when defending these views (White 2005 (2002), p. 42).

At any rate, the things listed by White as valuable contributions of Art as Experience have been a central focus of this article.

\subsection{Hans Joas on the Importance of Creativity}

A contemporary pragmatist sociologist who has developed a social theory that builds on Dewey's aesthetics is the German sociologist Hans Joas. He has applied Dewey's aesthetics in his theory of 'creative action'. According to Joas, two broad, general models of action traditionally dominate in sociology - the rational action model and the normatively oriented action model - and both are blind to the irreducibly creative character of human action. Human behaviour is neither fully captured by rational considerations or interests, nor by normative rules. He, therefore, suggests a third model - a creative action model that takes Dewey's Art as Experience as one of its main guides (Joas 1996, pp. 4-5). Joas emphasizes that Dewey's reflections on creativity should not be treated as something that is only relevant within the context of art, but as something that affects the full range of human behaviour (Joas 1993, p. 5). Hence, Joas claims that Dewey's extensive discussions of high art in Art as Experience should not lead to the conclusion that the aesthetic is 'the preserve of geniuses'. Dewey's aesthetic dimension is present in all experience, and all human beings can have access to 'the self-created meaningfulness of what one does' (Joas 1996, p. 140).

For Joas, pragmatism more generally is 'a theory of situated creativity' (Joas 1996, p. 133). This notion captures concisely how Dewey reconstructed the complex and varied positions social actors find themselves in when they make a decision or choose a course of action and shows that these go well beyond instrumental logic, functional necessity or rational choice. It is a description - albeit in a more 
generalized form - of the problem-solving by social actors that is not very dissimilar to the ones provided in the neo-pragmatist descriptions of science.

It is indeed true that the pragmatists attempt to anchor creativity in the actions of human beings in their natural and social environment. The natural conditions of the environment figure just as strongly in this way of thinking as do the physical attributes of the human being. All action is embedded in anthropological structures of communication. Yet, creativity is more than merely one of the necessities for the survival of an organism. A problem of action is not only given when the organism is in fundamental danger; action constantly encounters unexpected obstacles: goals show themselves to be unattainable; simultaneously pursued goals prove to be mutually exclusive; attainable goals have doubts cast upon them by other actors. In these various crises of habitual action, the action situations have to be redefined in a new and different way (Joas 1996, pp. 132-133).

Social actors are not only presented with forced moves by their natural and social environment, they are also confronted with novel and open-ended choices that will force them to imagine new solutions and formulate creative new responses. Joas touches on a great many topics, but in the context of this article, the application of his theory to the professions needs to be mentioned briefly. According to Joas there is a deep human need to engage in meaningful action, and to express it in your work, if you can. Studies, he contends, indicate that current generations in the West prefer professions or roles that are characterized by concepts like expressivity, creativity or authenticity, and that people in careers that do not allow for such creativity 'tend to craft their private life as if it were a work of art' (Joas 1996, pp. 252-253). It seems people look for 'self-created meaningfulness'. If they do not find it in their work, their aesthetic impulse finds expression in their private lives. An impulse, one could hypothesize, that has since found an outlet in social media, where the self-dramatization of private lives has become ubiquitous.

\subsection{Mark Johnson and Stephen Winter: Pragmatist Aesthetics, Cognitive Science and Law}

A theorist for whom Art as Experience is a seminal book that even today is pregnant with insight into the way people understand the world is Mark Johnson. Dewey's observations and speculations on the role of aesthetics in the way people perceive and understand the world were groundbreaking, Johnson argues. They inform, and are increasingly supported by, research in cognitive science and cognitive linguistics. ${ }^{16}$ This paradigm shift in the understanding of language (at least from Johnson's perspective) also has implications for legal understanding - a topic that Johnson has discussed himself, but that has also been elaborated on by the legal theorist Steven Winter. 
If Rorty claims that John Dewey's talk of experience led American philosophers to stop reading him and turn their focus on language, then Johnson argues cognitive linguistics is increasingly showing that the linguistic turn was a wrong turn and that Dewey had it right all along. John Dewey gave a pretty good description of the way the human mind and the human body are engaged in perceiving and understanding our surroundings and in forming it into concepts and patterns of thought. What the linguistic turn did was take our bodies out of this equation. With the possible exception of Wittgenstein and Putnam, Johnson argues,

[t]he overwhelming tendency in mainstream analytic philosophy of language is to begin with concepts more or less well formed, and to analyze their relations to one another in propositions and to objects of reference in the world. This leads one to overlook the bodily origins of those concepts and patterns of thought that constitute our understanding of, and reasoning about, our world. (Johnson 2017, p. 6)

Cognitive linguistics has shown that this is not how language works. When you conceptualize, talk or reason about objects, you activate the same neural processes in the brain that you apply to use, move around or relate to those objects:

There are not two different and independent systems, one for perception and another for conception; to conceive some object is a matter of engaging in a simulation process that activates selective sensory and motor aspects of that object and our typical physical and cultural interactions with it. (Johnson 2017, p. 23)

We think with a workaday brain that has developed to do practical things such as move around, size up the surroundings and relate to others. Our thinking is fundamentally shaped by the neural patterns that allow us to do that. Our brains form 'image schemas', which are a basic ingredient for our understanding. We also make basic categorizations and bootstrap our way up through analogy and metaphorical extensions to more complex understanding. This, moreover, is a process infused with emotion, not of making purely analytical distinctions. Just like Dewey in Art as Experience differentiated between an 'experience at large' and 'having an experience', cognitive science suggests that emotion plays a large role in the selection of the aspects of our experience that form the stuff of our thoughts: 'The abstractions that populate our thinking do not transcend such feelings; rather they are selections of discriminable felt qualities and patterns abstracted from the much-at-oneness [...] of any given experience' (Johnson 2017, pp. 65-66).

Johnson has fleshed out his cognitive linguistics with much more specificity and has applied it to law, among other topics. The view from cognitive linguistics on conceptualization and categorization mainly differs from that of the classical objectivist notion of categories that typically informs legal theory in that it allows more flexibility in application. Johnson contends that the classical objectivist theory of categories, with its reliance on an exhaustive set of necessary characteristics to distinguish what truly belongs to the category, is almost certainly false. Cogni- 
tive research shows that people reason and think through analogy, that they use basic prototypes and basic bodily experiences metaphorically and extend them to more complex concepts and understandings. Key concepts, not only in law but in every academic discipline, according to Johnson, 'are defined by multiple, often inconsistent metaphors, and we reason using the internal logic of those metaphors' (Johnson 2007, p. 866).

The legal theorist Steven Winter has applied this brand of cognitive linguistics to reconstruct legal theory and legal reasoning. His argument covers a wide range of topics and evades brief description, but on the importance of embodied linguistics within law, he is quite close to Johnson (Winter 2001, p. 103). Cognition, Winter argues, 'is not principally representational, propositional, or computational, but rather involves processes that are imaginative, associative and analogical' (Winter 2001, p. 5). This is true of law just as much as any other discourse.

One of the legal theorists that Winter singles out for praise in his work is the famous Legal Realist Karl Llewellyn. What is most interesting about Llewellyn, Winter claims, is not his formulation of the 'fact skepticism' and 'rule skepticism' that the Realists are famous for, but what he calls the 'epistemic dimension' of his Realist legal theory. Oliver Wendell Holmes, who had incorporated pragmatist philosophy into his legal thought, had coined some of the central tenets that underpinned Legal Realism, like the idea that 'the life of the law' had not been logic but experience, and the instruction to 'think things not words'. However, Holmes' own work in law was quite standard doctrinal legal argument and did not put his pragmatist notions into practice. Llewellyn, on the other hand, did take Holmes' pragmatist tenets seriously and actually applied them in his legal theory. These were the same pragmatist ideas that cognitive scientists, as we saw earlier, adopted in their research, that is, the central importance of experience for the construction of meaning and categories. Llewellyn, in other words, managed to formulate a view of law in the first part of the 20th century that is consonant with the latest research in cognitive science. If Llewellyn would have been alive today, according to Winter, he would have turned to that field to better understand law (Winter 2001, p. 42).

One of the 'epistemic dimensions' of Llewellyn's theory discussed by Winter is the constant change of legal categories and concepts, the dependence of their meaning on lawyers' situation sense and the need of their constant adaptation to provide legal certainty. Llewellyn did not see law as a static order that simply had to be enforced. Instead, it was more like an order that was constantly being disturbed by social change and that had to be actively maintained to not be thrown off balance. Legal certainty, Llewellyn argued paradoxically, could only prevail through change. If a judge made a decision that did not keep up with the latest changes in society, her decision would be seen as conservative; if she followed the pace of social change exactly, however, nobody would notice that a change had occurred and all would be content that stare decisis had prevailed. For lawyers to apply categories and concepts flexibly to new conditions, yet in a way that seemed continuous with their ostensible meaning, was something, Llewellyn believed, that required them to have 'situation sense'. Situation sense was a mixture of intuition, experience and practical knowledge. This situation sense was something that a skilled practitioner, a legal craftsman, would possess and that would keep the law predictable. Situation 
sense has received a lot of criticism for being vague or for acquiescing in the prejudices of lawyers, but Winter believes this is unjust. Winter contends that situation sense is 'remarkable in its descriptive adequacy'. Situation sense is a concept that 'encompasses precisely the qualities of reflexivity, cultural commonality, and experientially grounded reason' that cognitive models use in their explanation of meaning. Llewellyn did not have the theoretical framework of cognitive linguistics, but like Dewey, he was ahead of his time (Winter 2001, pp. 216-219).

\section{Law as Art}

Although Winter's tribute to the epistemic dimension of Llewellyn's legal theory offers a good starting point, and although there are suggestive beginnings in the several ways that Dewey's reflections on art and aesthetics have been taken up in the pragmatist revival, it may not be immediately clear how, exactly, Dewey's aesthetics can be made relevant to law and legal education. As we saw, the authors described in the middle section often do not agree amongst themselves on the significance of Dewey's legacy. While Rorty rejects the central notion in Dewey's Art as Experience - namely 'experience' - as an embarrassing misconception people used to have, he nonetheless lauds Dewey's embrace of, for instance, Walt Whitman's view that 'the United States are themselves the greatest poem' (Rorty 1999, p. 24). ${ }^{17}$ This perspective, Rorty claims, should only be seen as a more attractive discourse, only be understood as a better way of talking about the American republic. Putnam, in turn, rejects Rorty's approach to pragmatism as corrosive postmodern relativism, and instead suggests ways to include values as part of the scientific explanations in economics or law. White, meanwhile, in his account of holistic pragmatism, seeks to frame aesthetics as a worthwhile scientific discipline in its own right. Mark Johnson, finally, criticizes mainstream philosophers of language - philosophers like the aforementined authors - for being stuck in an 'armchair enterprise motivated primarily by the desire to show how knowledge is possible by showing how language can map onto the world and express truth claims' (or how it is not possible, in the case of Rorty). These philosophers, Johnson argues, are working with a narrow and 'impoverished conception of language'. By giving up Dewey's notion of experience, he believes, they fail 'to understand the central importance of embodiment for all meaning, thought and language' (Johnson 2017, p. 225).

While all these problems are real, Art as Experience does seem strongly suggestive of a certain approach to law and education. Some of the authors in the middle section largely stay away from any fundamental philosophical disagreements and just focus on the general picture that emerges from Art as Experience. Joas emphasizes the ineluctable creativity to be found in human action and its importance for understanding social phenomena. And Shusterman in his general theory of somaesthetics tries to fuse Rorty's celebration of art and literature with Dewey's recognition of the ubiquity of aesthetics in human experience and cognitive science's 
notion of embodiment, without dwelling on the fundamental disagreements that exist between these different perspectives. For the consideration of the importance of pragmatist aesthetics for law, it may be more fruitful to focus on what these perspectives have in common rather than what divides them. Maybe we should think of neo-pragmatist aesthetics as an overlapping consensus. Whether you think that you should try to reconstruct analytical philosophy from within to open it up to values and aesthetics or you think that, without any empirical method to decide between vocabularies, it is best to choose the one that is more interesting and attractive or you think that aesthetics is an integral part of human cognition, then, at least, you agree that aesthetics is a dimension of the way people understand the world. What all authors suggest is that creativity and expressiveness are a central feature of all human action and that this aspect is not some embellishment, but a vital part that shapes not only the work of the artist, but also the scientist, the craftsman and the lawyer. It is embedded in, although not limited to, the very language we use.

Dewey maintained that language itself was a social work of art. It was not a work of art to last for the ages, but subject to pressures of change. Shelley, we saw, believed poets 'were the unacknowledged legislators of the world' - their art involved seeing new connections, creating new meaning and making the world new through fresh metaphors. This work was perishable, Shelley believed. Poetic metaphors lost their vitality over time. In A Defense of Poetry, Shelley writes of the universal human urge of 'mimetic representation':

Those in whom it exists in excess are poets, in the most universal sense of the word; and the pleasure resulting from the manner they express the influence of society or nature upon their own minds, communicates itself to others, and gathers a sort of reduplication from that community. Their language is vitally metaphorical; that is, it marks the before unapprehended relations of things and perpetuates their apprehension, until the words which represent them, become, through time, signs for portions of classes of thoughts instead of pictures of integral thoughts; and then if no new poets should arise to create afresh the associations which have been thus disorganized, language will be dead to all the nobler purposes of human intercourse. (Shelley 2006 (1821), pp. 653-654)

The Shelleyan point that concepts can grow stale is what Dewey stressed about law. In his article 'Logical Method and Law', Dewey observed, 'It is in the nature of any concept, as it is of any habit to change more slowly than do the concrete circumstances with reference to which it is employed'. This conceptual conservatism filled a psychological need, Dewey suggested, and afforded people 'a specious sense of protection, of assurance against the troublesome flux of events' (Dewey 1924, p. 20). Eventually such conservatism would lead to a system of law out of step with the circumstances it needed to regulate. Hence, the work of lawyers should not simply involve drawing logical conclusions from given premises; rather, their work should involve creatively reframing general principles and specific facts in such a way that they are 'worthy to serve as premises' (Dewey 1924, p. 23). 


\subsection{Karl Llewellyn, Education and the Aesthetics of Law}

Karl Llewellyn picked up many of the themes from Dewey that are prominent in the neo-pragmatist accounts of aesthetics and to a large degree already embodied in the 'overlapping consensus' I suggested. Llewellyn applied a lot of the pragmatist insights in his approach to law and legal education. Llewellyn had the same urge to naturalize law, as Dewey had to naturalize philosophy and art; the same appreciation of the art and creativity in law, as Dewey had for human action more generally; and the same acceptance of the need to renew and refresh the vocabulary of law to adapt it to changing conditions and keep it from growing stale, as Dewey had for social institutions overall. Moreover, like Dewey, he admired the ideal of the medieval workshop and the ethic of craftsmanship. Finally, Llewellyn, in the words of Twining, was 'extremely influential as a teacher, educator, and general stimulator' (Twining 1993, p. 121). Legal Realism, after all, in an important way, was a movement to reform legal education and the American law school.

In a set of lectures at the University of Chicago in 1941, Karl Llewellyn set out his view of law generally. These lectures were published, in part, in the article 'On the Good, the True, the Beautiful, in Law'. In a footnote accompanying the title, Llewellyn described vividly what concerns he thought were being wedded in the institution of law: concerns about 'justice, efficiency and warmth' (the good), with concerns about 'objectively verifiable truth', 'truth of other kinds' and of 'finding and stating true law' (the true) and, finally, 'the esthetics of legal craftmanship' and 'the esthetics of substance' (the beautiful), which verged back into the 'good' on the one hand and the 'true' on the other (Llewellyn 1942, p. 224n). The types of concerns that Llewellyn thought had a bearing on the administration of law could very well have been suggested by Dewey, too. Note, also, that the aesthetic dimension of legal craftsmanship and of substance are not simply superfluous adornments, but things that were an integral part of law and tied in with 'the true' and 'the good'. Many aspects that Legal Realism is noted for are there - the turn to social science, the melioristic drive to promote social well-being, the celebration of things that work - but everything is infused with an aesthetics of craftmanship and work well done.

It is interesting that Llewellyn introduces the character of Diogenes Jonathan Swift Teufelsdröckh in the article, as a philosopher of law who had 'a rich understanding for form, for the significance peculiarly to law of the garb of means which requires to be laid upon reason, goal, or meaning' (Llewellyn 1942, p. 225). The invention of this character was a reference to Thomas Carlyle, who created an imaginary Diogenes Teufelsdröckh, philosopher of clothes, in his book Sartor Resartus (2000 (1834)). Sartor Resartus was an unusual mix of parody, essay and autobiography by Carlyle. (Carlyle was another British Romantic who was widely read by American Transcendentalists and was a major influence on Emerson.) Sartor Resartus literally means 'the tailor retailored'. It expounds the 'clothes philosophy', a theory about the appearances of things and their reality. The appearance of a person depends on the costume she wears; the reality of the person, however, is the body underneath the costume. Over the years the clothes might wear out, but the person underneath will still be vital. It was the same with institutions - over time 
their outer husk, 'the garb of means' (as Llewellyn phrases it), might wear out, while their spirit remains vital and something important to reinvigorate.

The 'retailoring' of the law might suggest a surface makeover, but that is not what Llewellyn (or Carlyle for that matter) had in mind. Maybe it is best to understand Llewellyn's concern for aesthetics in the framework of his overall functionalist understanding of law - his law-job theory. In Llewellyn's functionalist perspective, the main purpose of the legal system was to keep the group together as a group and to make sure that disputes and conflicts were disposed of before they could disrupt the group's stability. The law-jobs consisted of five basic functions, such as 'the disposition of trouble cases' and 'the preventive channeling and reorientation of conduct and expectations' to avoid conflict. The final overarching lawjob was the job of juristic method (Llewellyn \& Hoebel 1987 (1941), p. 293). This last law-job should not be confused with 'legal method', which was focused on litigating a case for a party. Juristic method involved the more general job of developing and maintaining the techniques, skills, devices, practices and traditions to do the other law-jobs well (Twining 1993, p. 119). The job of juristic method, Llewellyn claimed, was about the manner of working. Hence, he believed, "juristic method is not dissimilar in nature from style in art” (Llewellyn \& Hoebel 1987 (1941), p. 308). The functionalism of his law-job theory should not be mistaken for a restrictive and guiding framework. On the contrary, Llewellyn claimed:

[T] he only esthetic rule which I recognize about adornment in relation to function is that adornment is best when it can be made to serve function, and is bad when it interferes with function; beyond that, the quest for richness of beauty and meaning seems to me the right quest. (Llewellyn 1942, p. 248)

This interest in the aesthetics of the legal craft also led Llewellyn to divide American legal history up into 'period styles', which he described as 'the pervading unmistakable manner of a period'. He distinguished a Grand Style in the early decades of the republic, for instance, and a Formal Style in the late 19th century. Such a 'period style' was 'not only applicable, but important, to work in law' ((Llewellyn 1942, p. 231). (Interestingly, Llewellyn took the periodization from Roscoe Pound, but what Pound had described as 'schools of jurisprudence', Llewellyn renamed 'period styles'.) Llewellyn described period style like a set of nudges: 'A "style" though strongly marked, is not a uniformity; it is, as it meets the learner in the craft, a set of pressures channeling technique and imagination, a set of pressures which have come (rarely by design) to interlock into a sensible whole' (Llewellyn 1942, p. 237). From the viewpoint of the philosophy of language this might have looked like woolly nonsense, but from the viewpoint of pragmatist aesthetics this makes perfect sense.

Llewellyn believed the craftsmanship of lawyers was necessary to keep law going as a social institution. They did this in part by keeping concepts relevant to a changing world. He wrote vividly about these skills in his notes for a lecture on the crafts of lawyers. In a section called 'stability and change in crafts', Llewellyn notes as follows: 
All patterns tend into routine; routine tends into woodenness. Errors in initial design of pattern continue; needed adaptations fail of discovery or acceptance. To vested inertia is added vested interest, vested habit, vested emotion and vested conviction. ${ }^{18}$

Good craftsmanship involved keeping the institution of law vital and relevant, to adapt it to evolving social circumstances. 'In a live craft', Llewellyn remarks, 'change comes constantly from within, via the craftsman's feeling for the changing needs of the felt job and via invention followed by imitation' (p. 509).

One could raise the question whether such Shellyan reimagination of language is not far too radical for law? Llewellyn, however, very much has the instincts of an institutionalist (in the colloquial sense) who is not looking for rupture, but evolution. Llewellyn makes a distinction between 'Drift' and 'Drive' in the development of law (Twining 1973, p. 508). 'Drift' involves the small-step, unplanned, incremental change of law. It is the result of the slow build-up of many small adaptations in the day-to-day legal decision-making. 'Drive', on the other hand, is change by design. 'Drive' is a label you would only attach to rare landmark decisions that lead to a paradigm shift. As an example of this, you could perhaps think of the famous Brown v. Board of Education decision that started the period of the Warren Court and the civil rights era. Very few lawyers may ever be in a position to 'drive' legal change, in this sense, but many are involved in legal 'drift', in the small-scale legal innovations that slowly change the law in the way that everyday speech slowly changes language, meaning and ways of speaking. The element of drift is all the more effectual when the drift is guided uniformly by a period style, when all the small changes vector in the same direction. The creativity of craftmanship is slow compared with the creativity of art. It is tempered by the process of imitation and apprenticeship.

Yet, how can this sort of creativity be fostered within the context of law and legal education? In the United States, arguably, the type of legal theory that Llewellyn represented has already had a marked influence. The benefits of integration between law and other disciplines are widely accepted and the curriculums typically offer a range of established Law-and... fields. The lessons of Legal Realism have been learnt. Americans like to claim they are all Realists, now (although Putnam's reservations about the strict fact/value distinction still hobbling law as a field might indicate there are still issues there, too, especially if you frame that distinction it in terms of pragmatist aesthetics). In Europe, however, there is not such a clear legacy from Legal Realism. It seems that in Europe lessons could still be learnt about the benefits of seeing law in a broader context and opening up to other disciplines. To understand law in a wider context, to see legal phenomena in a different light, provides a student with a different perspective and gives her a different vantage point to judge a given concept or rule by. Dewey makes this argument vis-à-vis high art and poetic metaphors, as we saw earlier, but the same notion could apply to a wider range of topics. A law and literature class could make a student see a certain legal conception differently, for example, make her question 
the established understanding of that conception and create space for different perspectives. But a comparative law or a legal history class could do the same, showing how legal systems in different cultures and different time periods defined a familiar category very differently. Obviously, the same could be said for philosophy, anthropology and sociology. These traditional Law-and...fields have become embattled in a lot of law departments, but they make a valuable contribution to legal education by extending the imagination of students.

A second way legal education can foster the development of craft skill and creativity is the classic pragmatist way - by practical, hands-on experience in the application of law. Experience is central to Dewey's theory of education, of course. 'I assume amid all the uncertainties', Dewey writes in Experience and Education, 'there is one permanent frame of reference: namely the organic connection between education and personal experience' (Dewey 1938, p. 25). So what would legal education through 'personal experience' mean within the context of Dewey's theory of art and aesthetics? In the context of law this translates into how James' 'blooming, buzzing confusion' of the social world can be fit into the concepts and categories of law and what to do when that fit becomes problematic. By being exposed not only to textbook cases, but also to messy particulars, you develop a feel for law as a tool for the organization of society, for the skills of juristic method.

\section{Conclusion}

The arc of the argument presented in this article is fairly stretched, so it is appropriate to recap the different sections, briefly, in the conclusion. In the first section, Dewey's understanding of aesthetics was elaborated upon. Dewey's aesthetics is a central notion in his overall pragmatic philosophy. Aesthetics is an aspect of the way people experience their environment, of the way they poetically see and conceptualize their world, of the objects they make and anthropological setting they inhabit, of their scientific understanding of reality and, finally, of their moral and legal concepts and the way these are interpreted and applied. Art and aesthetics should be integral to all aspects of social life (including law). The compartmentalization of art in the modern world is a sign of dysfunctionality and a cause for reform.

The second section discussed the way Dewey's aesthetics still plays a role in contemporary pragmatist philosophy, especially vis-à-vis epistemology. The philosopher who is most responsible for the rediscovery of pragmatist aesthetics in recent decades, Richard Rorty, presents a fairly truncated version of Dewey's aesthetics. Rorty rejects Dewey's naturalization of aesthetics, that is, his grounding of aesthetics in experience. Following Dewey, Putnam and White both try to extend mainstream conceptions of science to encompass values and aesthetics, respectively. Joas, in turn, reconceived pragmatism as a theory of 'situated creativity', that is, a theory of how social actors are not simply led by rationality, or by normative guidelines when they act, but often draw on elements in their social and cultural setting to frame genuinely creative alternatives. Lastly, Johnson and Winter reconnect with the notion of experience central to Dewey's aesthetics and argue that it 
foreshadowed the insights of cognitive linguistics that have important consequences for law.

Finally, in the last section, these insights have been applied to law and legal education. Pragmatist aesthetics suggests that the way lawyers can remake and reimagine the world is through fresh metaphors and the reframing of concepts in order to keep them relevant to a changing world. This is best conceived as piecemeal and incremental adaptation in everyday legal practice. In order to prepare law students for this type of slow reconceptualization of law, two aspects of legal education could be promoted. First, legal education should cherish their Law-and... subjects, most obviously Law-and-Literature, but also other topics like Law-and-Society, Legal History or Legal Anthropology. These topics expose students to alternative legal understandings and the could-be-otherwise nature of legal concepts. Second, students benefit from experiencing the practical application of law to real-world fact situations as realistically as possible. Obviously, the kind of craftsmanship and aesthetic feel that Dewey and Llewellyn seem to suggest for the creative application of law is something that is most likely to develop with years of practical legal experience, but there is no need to obstruct that development by instilling in law students an undue respect for the fixity of law.

\section{References}

Barnes, Alfred C. (1947). Art and Education, 2nd Edition Enlarged and Revised, Merrion, PA: Barnes Foundation Press.

Blake, William (1996 (1804)). "Preface to Milton: A Poem in Two Books" (“Jerusalem") in: J.M. Dent (ed.). William Blake: Selected Poems. London: Everyman, p. 124.

Carlyle, Thomas (2000 (1834). Sartor Resartus: The Life and Opinions of Herr Teufelsdröckh. Oxford: Oxford World Classics.

De Been, Wouter (2015). "Pragmatism and Dynamics: Does Pragmatist Adjustment Go All the Way Down?," Erasmus Law Review, Vol. 8, No. 1, pp. 26-37.

De Been, Wouter, and Sanne Taekema (2012). "De verstrengeling van feiten en waarden: Onjuist of onvermijdelijk?” in: E.T. Feteris e.a. (red), Gewogen oordelen. Essays over argumentatie en recht, Den Haag: Boom, pp. 327-337.

Dewey, John (1924). "Logical Method and Law," Cornell Law Review, Vol. 10, No. 1, pp. 1727.

Dewey, John (1977). The Poems of John Dewey: Edited with an Introduction by Jo Ann Boydston, Carbondale, IL/Edwardsville, IL: The Southern Illinois University Press.

Dewey, John (1988 (1930)). "Qualitative Thought," in: The Symposium 1, 5-32. Reprinted in Dewey 1925-1953, Later Works 5: 243-262.

Dewey, John (1997 (1925)). Experience and Nature, Chicago \& La Salle: Open Court.

Dewey, John (2005 (1934)). Art as Experience, London: Penguin.

Dewey, John (2015 (1938)). Experience and Education, New York: Free Press

Fowler, Don D. (2003). "A Natural History of Man: Reflections on Anthropology, Museums, and Science," Fieldiana. Anthropology, No. 36, pp. 11-21.

Gura, Philip F. (2007). American Transcendentalism: A History, New York: Hill and Wang.

Hein, George E. (2017). “John Dewey and Albert C. Barnes: A Deep and Mutually Rewarding Friendship," Dewey Studies, Vol. 1, No 1, pp. 44-78.

Joas, Hans (1993). Pragmatism and Social Theory, Chicago: University of Chicago Press.

Joas, Hans (1996). The Creativity of Action, Chicago: University of Chicago Press.

Johnson, Mark (2007). “Mind, Metaphor, Law," Mercer Law Review, Vol. 58, pp. 845-868. 
Johnson, Mark (2017). Embodied Mind, Meaning, and Reason: How Our Bodies Give Rise to Understanding, Chicago, IL/London: University of Chicago Press.

Kaplan, Abraham (1987). "Introduction," in: John Dewey (ed.), The Later Works. Vol. 10, Carbondale, IL: Southern Illinois University Press, pp. vii-xxxiii.

Kultermann, Udo (1990). “John Dewey's 'Art as Experience': A Revaluation of Aesthetic Pragmatism," Art Criticism, Vol. 6, No. 3, pp. 17-27.

Llewellyn, Karl N. (1942). "On the Good, the True, the Beautiful, in Law," The University of Chicago Law Review, Vol. 9, No. 2, pp. 224-265.

Llewellyn, Karl N. (2016 (1960)). The Common Law Tradition: Deciding Appeals, New Orleans: Quid Pro Books.

Llewellyn, Karl N., and E. Adamson Hoebel (1987 (1941)). The Cheyenne Way: Conflict and Case Law in Primitive Jurisprudence, Norman, OK: University of Oklahoma Press.

Menand, Louis (2001). The Metaphysical Club: A Story of Ideas in America, London: Flamingo. Mollard, Romain (2013). “The Role of Imagination in James's and Dewey's Understanding of Religious Experience," European Journal of Pragmatism and American Philosophy, Vol. 1 Pragmatism and Creativity, pp. 1-10.

Putnam, Hilary (1995). Pragmatism: An Open Question, Oxford/Cambridge: Blackwell.

Putnam, Hilary (2002). The Collapse of the Fact/Value Dichotomy and Other Essays, Cambridge/London: Harvard University Press.

Putnam, Hilary, \& Ruth Anna Putnam (2017). Pragmatism as a Way of Life: The Lasting Legacy of William James and John Dewey, Cambridge, MA/London: The Belknap Press.

Quine, W.V.O. (1953). “Mr Strawson on Logical Theory,” Mind, Vol. 62, pp. 433-451.

Quine, W.V.O. (1960). “Carnap and Logical Truth," Synthese, Vol, 12, No. 4, pp. 350-374.

Rorty, Richard (ed.) (1992 (1967)). The Linguistic Turn: Essays in Philosophical Method With Two Retrospective Essays, Chicago/London: The University of Chicago Press.

Rorty, Richard (1998), Achieving Our Country: Leftist Thought in Twentieth-Century America, Cambridge, MA/London: Harvard University Press.

Rorty, Richard (1999). Philosophy and Social Hope, London: Penguin.

Shelley, Percy Bysshe (2006 (1821)). "A Defense of Poetry" in: Jack Donovan and Cian Duffy (eds.). Percy Bysshe Shelley: Selected Poems and Prose, Milton Keynes: Penguin Classics, p. 651-678.

Shusterman, Richard (2010). "Pragmatism and Cultural Politics: From Rortian Textualism to Somaesthetics," New Literary History, Vol. 41, No. 1, pp. 69-94.

Shusterman, Richard (2013). "Affective Cognition: From Pragmatism to Somaesthetics," Intellectica, Vol. 60, pp. 49-68.

Shusterman, Richard (2014). "The Invention of Pragmatist Aesthetics: Genealogical Reflections on a Notion and a Name," in: Wojciech Malecki (ed.), Practicing Pragmatist Aesthetics, Amsterdam: Brill/Rodopi, pp. 11-32.

Sooke, Alistair (2015). "Albert Barnes: The 'Monster' Who set Matisse Free," The Telegraph, December 5.

Twining, William (1973). Karl Llewellyn and the Realist Movement, Norman, OK: University of Oklahoma Press.

Twining, William (1993). "The Idea of Juristic Method: A Tribute to Karl Llewellyn," University of Miami Law Review, Vol. 48, pp. 119-158.

Vogel, Morris J. (1991). Cultural Connections: Museums and Libraries of Philadelphia and the Delaware Valley, Philadelphia, PA: Temple University Press.

West, Cornel (1989). The American Evasion of Philosophy: A Genealogy of Pragmatism, Madison, WI: The University of Wisconsin Press.

White, Morton (2005). From a Philosophical Point of View: Selected Studies, Princeton, NJ/ Oxford: Princeton University Press.

White, Morton (2005 (2002)). A Philosophy of Culture: The Scope of Holistic Pragmatism, Princeton, NJ/Oxford: Princeton University Press. 
Wouter de Been

Winter, Steven L. (2001). A Clearing in the Forest: Law, Life and Mind, London/Chicago, IL: The University of Chicago Press. 